\title{
Frequency of Mycoplasma hominis and Ureaplasma urealyticum infections in women with systemic lupus erythematosus
}

\author{
Freqüência da infecção pelo Mycoplasma hominis e Ureaplasma urealyticum \\ em mulheres portadoras de lupus eritematoso sistêmico
}

Alcyone A. Machado ${ }^{1}$, Alessandro R. Zorzi ${ }^{1}$, Ana Eugênia A. Gléria² and Eduardo A. Donadi ${ }^{1}$

\begin{abstract}
Resumo Ureaplasma urealyticum (UU) e Mycoplasma hominis (MH) têm sido detectados em urina de mulheres com lupus eritematoso sistêmico (LES). Avaliamos a presença destes mycoplasmas no endocervix de mulheres apresentando LES. Um total de 40 pacientes com LES (idade média de 40,2 anos), e 51 mulheres sadias (idade média de 30.9 anos), foram estudadas. Swabs do endocervix foram cultivados em meio líquido específico para $\mathrm{MH}$ e UU, detectados por teste colorimétrico quantitativo, considerando positivo diluiçóes $>10^{3}$. Análise estatística foi feita usando teste de Fisher. UU foi detectado em $52,5 \%$ das pacientes e em $11,8 \%$ dos controles $(p=0.000059)$. MH foi detectado em $20 \%$ das pacientes e $2 \%$ dos controles $(p=0.003905)$. Ambos mycoplasmas foram detectados em $7,3 \%$ das pacientes e $0 \%$ dos controles $(p<0.000001)$. Os resultados aqui reportados corroboram com a associação de infecção por mycoplasma e LES. Estes agentes podem estimular a produção de clones autoreativos.
\end{abstract}

Palavras-chaves: Mycoplasma. Lupus eritematoso sistêmico. Mycoplasma hominis. Ureaplasma urealyticum. infecção genital.

Abstract Ureaplasma urealyticum (UU) and Mycoplasma hominis (MH) have been detected in the urine of
women with systemic lupus erythematosus (SLE). We evaluated the presence of these mycoplasma in the
endocervix of women presenting SLE. A total of 40 SLE patients (mean age 40.2 years), and 51 healthy women
(mean age 30.9 years), were studied. Endocervical swabs were cultured in specific liquid media for MH or UU,
detected by a quantitative color assay, and considered positive at $>10^{3}$ dilutions. Statistical analysis was performed
using the two-tailed Fisher test. UU was detected in $52.5 \%$ of patients and in $11.8 \%$ of controls ( $p=0.000059)$.
MH was detected in $20 \%$ of patients and $2 \%$ controls $(p=0.003905)$. Both mycoplasmas were detected in $7.3 \%$
patients and $0 \%$ controls ( $p<0.000001)$. The results reported here corroborate the association of the mycoplasma
infection and SLE. Thus, these agents may stimulate the production of autoreactive clones. Key-words: Mycoplasma. Systemic lupus erythematosus. Mycoplasma hominis. Ureaplasma urealyticum. Genital infections.

Systemic lupus erythematosus (SLE) is an autoimmune disease of connective tissue involving various organs and having a broad spectrum of clinical presentation, with periods of exacerbation and remission. Several immunological alterations are involved in the disease. The disease predominates among young women and its etiology is unknown, probably being multifactorial. Genetic, hormonal, immunological and environmental factors have been implicated in its etiopathogeny. Among the environmental factors, we may mention the participation of sunlight, of medications and of infections induced by viruses or other microorganisms ${ }^{71117}$.

Mycoplasma hominis (MH) and Ureaplasma urealyticum (UU) belong to the family Mycoplasmatacea, which is considered to include the smallest free-living microorganisms in nature. Their size is intermediate between bacteria and viruses. They differ from the former by the lack of a cell wall and from the latter by the fact that they grow in cell-free media ${ }^{3416}$

The lack of a cell wall in microorganisms of the family Mycoplasmatacea permits their direct contact with host

\footnotetext{
1. Faculdade de Medicina de Ribeirão Preto da Universidade de São Paulo. Conselho Nacional de Desenvolvimento Científico e Tecnológico-CNPq, 2. Hospital das Clínicas da Faculdade de Medicina de Ribeirão Preto da Universidade de São Paulo.

Financial Support: CNPq and FAEPA.

Address to: Dra. Alcyone A. Machado, Faculdade de Medicina de Ribeirão Preto/USP. Av. Bandeirantes 3900, 14049-900 Ribeirão Preto, SP, Brasil.

Phone: 5516633 0436, Fax: 55166336695

e-mail: aamachad@fmrp.usp.br

Recebido em 26/9/2000.
} 
cells leading to the exchange of cellular elements/ substances between these agents and the tissue involved, with the consequent triggering of autoimmune reactions. Their ability to induce activation of B and T lymphocytes and of cytokines, with the possible production of superantigens has been demonstrated in vitro 12568912 .

$\mathrm{MH}$ and UU are usually found on the mucosal surface of the urogenital tract. Transmission occurs by sexual intercourse or during delivery. Among women they are associated with cervicitis and colpitis, with pelvic inflammatory disease, infertility, spontaneous abortion, fetal prematurity, puerperal endometritis, and pyelonephritis. Colonization has been linked to young age, precarious socioeconomic condition, promiscuity, black race, and use of oral contraceptives, among other factors 341314181920.

$\mathrm{MH}$ and $\mathrm{UH}$ have been recently implicated in the pathogeny of SLE ${ }^{10} 17$ The participation of these microorganisms in the etiology or the prognosis of SLE in women has not been fully established. Thus, in the present study we evaluated the occurrence of $\mathrm{MH}$ and $\mathrm{UH}$ among women with SLE and compared it to the occurrence of these agents among healthy women.

\section{PATIENTS AND METHODS}

Cases: The study was conducted on 40 female patients with SLE seen at the Collagen Disease Outpatient Clinic of the University Hospital, Faculty of Medicine of Ribeirão Preto, who fulfilled the diagnostic criteria for SLE of the American College of Rheumatology?.

Fifty-one women with no previous diseases were recruited as controls from the patients who sought a gynecology clinic in the town of Ribeirão Preto for routine annual examinations.

All women gave informed consent to participate in the study.

Women suspected to be pregnant were excluded. All women participating in the study were sexually active.

Interview: The selected women were interviewed in order to obtain data about age, race, parity, age at first coitus, use of a condom by their partners and use of hormonal contraceptives, number of partners, frequency of sexual relations, and disease history.

Information about urologic, gynecologic and obstetric antecedents and regarding current medication were obtained from the medical records of the patients.

Material collection: Endocervical specimens were obtained from all women using a sterile device (Culturette ${ }^{\circledR}$ - Becton Dickinson and Company) and an appropriate technique in order to avoid contamination. The swab was immediately dropped into a tube containing $3 \mathrm{ml}$ transport medium appropriate for mycoplasmas ( $10^{1}$ dilution), taken to the laboratory and stored at $-20^{\circ} \mathrm{C}$ until the time for seeding (no longer than 24 hours of storage). The transport medium consisted of $1.7 \mathrm{~g}$ pancreatic casein digestion (bacto casitone), $0.3 \mathrm{~g}$ papain soy digestion (soy peptone), $0.25 \mathrm{~g}$ dextrose, $0.5 \mathrm{~g}$ dipotassium phosphate, and 99 $\mathrm{ml}$ deionized and twice-distilled water. This solution was autoclaved at $121^{\circ} \mathrm{C}$ for $20^{\prime}$ and $0.025 \mathrm{ml}$ sterile Lcysteine hydrochloride (a $4 \%$ solution) was added, plus
$1 \mathrm{ml}$ PPLO serum fraction, $0.004 \mathrm{ml}$ amphotericin $\mathrm{B}$, and 100,000 IU potassium penicillin-G.

Mycoplasma detection ${ }^{14}$ : The following appropriate and selective culture media were used:

a) for $\mathrm{MH}: 2.8 \mathrm{~g}$ PPLO broth, $140 \mathrm{ml}$ deionized and twice-distilled water, and $0.2 \mathrm{ml} 2 \%$ phenol red. The medium was autoclaved at $121^{\circ} \mathrm{C}$ for 15 minutes and $40 \mathrm{ml}$ horse serum was added, plus $20 \mathrm{ml}$ yeast extract, $1.32 \mathrm{ml} \mathrm{L}$-arginine hydrochloride (a $30 \%$ solution), $2 \mathrm{ml}$ VX supplement, and 100,000 IU potassium penicillin$\mathrm{G}$ (final $\mathrm{pH} 7.0,1 \mathrm{~N} \mathrm{NaOH}$ ).

b) for UU: $2.8 \mathrm{~g}$ PPLO broth, $140 \mathrm{ml}$ deionized and twice-distilled water, $2 \%$ phenol red, $\mathrm{pH} 5.5$, with a $2 \mathrm{~N} \mathrm{HCl}$ solution. The medium was autoclaved at $121^{\circ} \mathrm{C}$ for 20 minutes and supplemented with $40 \mathrm{ml}$ horse serum, $20 \mathrm{ml}$ yeast extract, $1 \mathrm{ml} 10 \%$ urea solution, $2 \mathrm{ml}$ VX supplement, and 100,000IU potassium penicillin$\mathrm{G}$ (final $\mathrm{pH} 6,1 \mathrm{~N} \mathrm{NaOH}$ ).

The diagnosis of genital infection with $\mathrm{MH}$ and or UU was based on culture of serial sample dilutions using $200 \mathrm{ml}$ specific medium in each U-bottom well of sterile disposable plates and $20 \mathrm{ml}$ of the sample in the first well. Serial dilutions of $10^{1}, 10^{2}, 10^{3}, 10^{4}, 10^{5}$, and $10^{6}$ were prepared. The plate was placed in an oven at $37^{\circ} \mathrm{C}$ protected with plastic film against evaporation. A first reading was taken at three days and a final one on the fifth day after seeding.

Samples were considered positive when the color of the medium turned from yellow to red in the case of $\mathrm{MH}$ and from red to purple in the case of UU for dilutions above $10^{3}$. The results are reported as Color Units. The test was considered to be negative when dilutions below $10^{3}$ were obtained.

Statistical analysis: Data were analyzed statistically by the two-tailed exact Fisher test, with the level of significance set at $\mathrm{p}<0.05$.

\section{RESULTS}

The mean age of the women with SLE was 40.2 years and the mean age of control group was 30.9 years.

Among the women with SLE, $62.5 \%$ were white, $30 \%$ mixed race and $7.5 \%$ black. Among the control women, $96 \%$ were white, $2 \%$ mixed race and $2 \%$ black. The difference between white and nonwhite women was significant between the two populations studied. 
The interviews applied to the two groups permitted the authors to obtain the data shown in Table 1. Age at first intercourse refers, on average, to the first vaginal coitus of the women, with other forms of sexual relations being excluded. The use of a condom refers to the regular and correct use of a condom by the sex partners for a

\begin{tabular}{|c|c|c|}
\hline & SLE & Control \\
\hline Age at $1^{\text {st }}$ intercourse & 20.7 & 21.1 \\
\hline Condom use & $3 \quad(7.5 \%)$ & $9(17.6 \%)$ \\
\hline Hormonal contraceptives & $5(12.5 \%)$ & $15(29.4 \%)$ \\
\hline \multicolumn{3}{|l|}{ Frequency of coitus } \\
\hline$>1 x /$ week & $22(59.0 \%)$ & $19(37.0 \%)$ \\
\hline $1 \mathrm{x} /$ week & $7(11.0 \%)$ & $29(57.0 \%)$ \\
\hline $1 \mathrm{x} /$ month & $1 \quad(3.0 \%)$ & $2(4.0 \%)$ \\
\hline abstinence & $10(27.0 \%)$ & $1(2.0 \%)$ \\
\hline \multicolumn{3}{|l|}{ № of partners } \\
\hline 1 & $29(72.5 \%)$ & $48(94.0 \%)$ \\
\hline$>1$ & $1 \quad(2.5 \%)$ & $2(4.0 \%)$ \\
\hline 0 & $10(25.0 \%)$ & $1(2.0 \%)$ \\
\hline
\end{tabular}

period of 1 year before the date of collection. The use of hormonal contraceptives, the frequency of coitus and the number of partners also refer to a period of 1 year before collection. The Fisher test showed significant differences between the two populations only with respect to number of partners, with a higher proportion of lupus patients practicing sexual abstinence for more than one year $(p=$ 0.00005 ), and with a greater proportion of control women having a single partner ( $p=0.007)$. The frequency of control women who had 1 relation per week was significantly higher $(p=0.0001)$ due to the greater proportion of abstaining women in the SLE group.
Table 2 compares the gynecologic, urologic and obstetric complications presented by women with SLE over the last 5 years in relation to the results of culture. Only the number of abortions differed significantly, with a greater occurrence in the group with negative cultures $(p=0.004)$.

Table 3 shows the numerical distribution of positive cultures obtained from endocervical material collected from the two groups. Of the 40 women with SLE, 21 (52.5\%) had positive cultures and 19 (47.5\%) negative cultures for Ureaplasma urealyticum; while for Mycoplasma hominis $8(20 \%)$ cultures were positive and $33(80 \%)$ were negative. These numbers include the

Table 2 - Genitourinary complications presented by women with SLE positive or negative for Mycoplasma hominis and Ureaplasma urealyticum over the last 5 years.

\begin{tabular}{lrrrr}
\hline & \multicolumn{2}{c}{ Positive $(\mathrm{n}=25)$} & \multicolumn{2}{c}{ Negative $(\mathrm{n}=15)$} \\
\cline { 2 - 5 } & $\mathrm{n}-$ & $\%$ & $\mathrm{n}^{\circ}$ & $\%$ \\
\hline Colpitis & 9 & 36.0 & 6 & 40.0 \\
Inflamatory pelvic disease & 1 & 4.0 & 1 & 6.7 \\
Herpes & 2 & 5.0 & 0 & 0 \\
Human Papilloma virus & 1 & 4.0 & 1 & 6.7 \\
Urinary tract infections & 4 & 16.0 & 0 & 0 \\
Pyelonephritis & 1 & 4.0 & 2 & 13.0 \\
Abortion & 1 & 4.0 & 4 & 27.0 \\
Prematury & 2 & 5.0 & 1 & 6.7 \\
Endometritis & 1 & 4.0 & 0 & 0 \\
Infertility & 1 & 4.0 & 1 & 6.7 \\
\hline
\end{tabular}

Table 3 - Numerical distribution of cultures positive for Ureaplasma urealyticum (UU), Mycoplasma hominis $(\mathrm{MH})$ or both microorganisms simultaneously among women with SLE and controls.

\begin{tabular}{lrrrr}
\hline Culture for & \multicolumn{2}{c}{$\operatorname{SLE}(\mathrm{n}=40)$} & \multicolumn{2}{c}{ Control s $(\mathrm{n}=51)$} \\
\cline { 2 - 5 } & $\mathrm{n}-\mathrm{o}$ & 52.5 & $\mathrm{n}$ & $\%$ \\
\hline $\mathrm{UU}^{1}$ & 21 & 20.0 & 6 & 11.8 \\
$\mathrm{MH}^{2}$ & 8 & 7.3 & 1 & 2.0 \\
$\mathrm{UU}+\mathrm{MH}^{3}$ & 3 & & 0 & 0 \\
\hline
\end{tabular}

$1-p=0.0000592-p=0.0039053-p<0.000001$ 
cultures that were simultaneously positive for the two microorganisms, for a total of three patients. The 51 women in the control group had $6(11.8 \%)$ positive cultures and $45(88.2 \%)$ negative cultures for $U$. urealyticum, and 1 (2\%) positive culture and 50 (98\%) negative cultures for $M$. hominis. In this group, no culture was simultaneously positive for the two microorganisms. These differences were statistically significant.

When the results of the cultures were compared in terms of the ethnic origin of lupus patients, white patients presented a significantly higher number of positive cultures for the two mycoplasmas than black women $(p=0.002)$.
On the basis of the information in the medical records it was possible to determine the medication the patients with SLE were taking during the collection period. Of the 40 women studied, 38 were taking prednisone, 16 were receiving cyclophosphamide pulses, 23 were taking chloroquine, and 8 were taking azathioprine. Eight patients had been recently taking antibiotics and one of them had been using a vaginal cream. Comparison of the medication, excluding prednisone, being taken with the culture results showed no significant difference for any of the above medications.

\section{DISCUSSION}

The present study showed that women with systemic lupus erythematosus have a higher frequency of genital infection with Mycoplasma hominis and Ureaplasma urealyticum compared to healthy women.

The difference in age between groups does not explain this fact, since the literature ${ }^{15}$ correlates young age with a higher frequency of infection. Since the lupus patients, on average, were older than the controls, we could expect a lower risk with respect to this variable.

The racial differences for the two groups probably did not affect the results since white women with SLE had a higher frequency of infection with both mycoplasmas compared to black women of the same group.

The sexual habits of the two populations were similar in terms of the use of hormonal and barrier contraceptive methods and in terms of age at first coitus. There were more lupus patients in sexual abstinence, a fact that might have minimized the frequency of infections in these patients, since the literature emphasizes that infection with the two agents is related to sexual promiscuity ${ }^{181920}$.

The use of medications that alter the immune response of women with lupus normally favors a higher frequency of infections in this group. However, when we compared women with positive cultures to women with negative cultures there were no significant differences between the medications used by the two groups.
On the other hand, it is important to observe the relevance of genital infection with mycoplasmas in SLE. Although, the comparison of the complications related to the urogenital system presented similar indices regardless of the result of culture, abortions were more frequent among women with negative cultures.

The increased frequency of infection with Mycoplasma hominis and Ureaplasma urealyticum among patients with SLE, reported in the present study, may suggest the participation of environmental factors in the pathogeny of SLE, as has been suggested in the study of Runge et al $(1997)^{17}$, which showed a higher frequency of Ureaplasma urealyticum infection in the urine of women with SLE.

The role of environmental factors in the development of autoimmune disease has not been fully elucidated. In vitro studies have suggested that these mycoplasma species can provoke polyclonal activation of B cells and production of superantigens ${ }^{5}$. The high frequency of genital infection among women with SLE suggests that these microorganisms may participate in the etiopathogeny of the disease.

It has been recently discussed that, in humans, mycoplasma peptides such as Mycoplasma arthritidis mitogen bind to the a chain of HLA-DR4, DR7 and DR12 1 molecules, and, to a lesser extent, to HLA-DQ ${ }^{6}$. Thus, it is possible that mycoplasma peptides may stimulate the production of autoreactive clones, as observed in SLE.

\section{ACKNOWLEDGMENTS}

We thank Mrs. Rita A S. Cardoso for technical assistance, Conselho Nacional de Desenvolvimento Científico e Tecnológico (CNPq) and Fundação de Apoio ao Ensino, Pesquisa e Assistência (FAEPA) for financial support.

\section{REFERENCES}

1. Alvarez-Ossorio L, Johannsen M, Alvarez-Ossorio R, Nicklas W, Kirchner H, Rink L. Cytokine induction by Mycoplasma arthritidisderived superantigen (MAS) but not TSST-1 or SEC 3 , is correlated to certain HLA-DR types. Scandinavian Journal of Immunology 47: 43-47, 1998.

2. Behar SM, Porcelli AS. Mechanism of autoimmune disease induction. The role of the immune response to microbial pathogens. Arthritis and Rheumatisme 38: 458-476,1995.
3. Bonissol C. Biologie des Mycoplasmas. Bulletin de la Mémorable Societé Medicale de Paris 8: 155-158, 1980.

4. Bonissol C. Donnés actuelles sur les Mycoplasmas. Association des Ancienes Élèves du Institute Pasteur de Paris 83: 8-14, 1980.

5. Cassell GH, Cole BC. Mycoplasmas as agents of human disease. New England Journal of Medicine 304: 80-89, 1981.

6. Cole BC, Sawitzke AD, Ahmed EA, Atkin CL, David CA. Allelic polymorphism at the $\mathrm{H}-2 \mathrm{~A}$ and $\mathrm{HLA}-\mathrm{DQ}$ loci influences the response of murine lymphocytes to the Mycoplasma arthritidis superantigen MAM. Infection Immunology 65: 4190-4198, 1997. 
7. Donadi EA, Petean FC, Voltarelli JC. Abordagem Clínica do Paciente Reumático. Medicina, Ribeirão Preto 25: 251-297, 1992.

8. Friedman SM, Posnett DN, Tumang JR, Cole BC, Crow MK. A potential role for microbial superantigens in the pathogenesis of systemic autoimmune disease. Arthritis and Rheumatism 34:468480,1991.

9. Furr PM, Taylor-Robinson D. Prevalence and Significance of Mycoplasma hominis and Ureaplasma urealyticum in the urine of a non-venereal disease population. Epidemiology Infection 98: 353-359, 1987.

10. Ginsburg KS, Kundsin RB, Walter CW, Schur PH. Ureaplasma urealyticum and Mycoplasma hominis in Women with Systemic Lupus Erythematosus. Arthritis and Rheumatisme 35: 429-433, 1992.

11. Hahn BH. An Overview of the Pathogenesis of Systemic Lupus Erythematosus. In: Wallace DJ, Hahn BH (eds) Dubois' Lupus Erythematosus. $5^{\text {th }}$ edition, Williams \& Wilknis, Baltimore, p.6976, 1997.

12. Iliopoulos AG, Tsokos GC. Immunopathogenesis and Spectrum of Infections in Systemic Lupus Erythematosus. Seminars Arthritis and Rheumatism 25: 318-336, 1996.

13. Kundsin RB, Poulin AS. Laboratory Diagnosis of Genital Mycoplasma Infection. Annals of the New York Academy of Sciences 549: 72-80, 1988.
14. Machado AA, Duarte G, Quintana SM, Paschoini MC, Bueno A, Gir E, Cardoso RAS. Infecção Genital Feminina por Mycoplasma hominis e Ureaplasma urealyticum e sua Relação com a Gravidez e a Infecção pelo HIV-1. Jornal Brasileiro de Doenças Sexualmente Transmissíveis 10: 5-8, 1998.

15. Mardh P, Elshibly S, Kallings I, Hellberg D. Vaginal Flora Changes Associated with Mycoplasma hominis. American Journal Obstetrics and Gynecology 176: 173-178, 1997.

16. Razin S. Characteristics of the mycoplasmas as a group. In Razin S, Tully JG (eds) Methods in Mycoplasmology. Academic Press, New York, volume I, p. 3-7, 1983.

17. Runge M, Rykena S, Wildhagen K, Deicher $\mathrm{H}$, Kirchloff $\mathrm{H}$. Detection of Ureaplasma urealyticum in Urine of Patients with Systemic Lupus Erythematosus and Healthy Individuals by Culture and Polymerase Chain Reaction. Journal of Medical Microbiology 46:413-418, 1997.

18. Taylor-Robinson D. Genital Mycoplasma Infections. Clinical and Laboratory Medicine 9: 501-523, 1989.

19. Taylor-Robinson D, McCormack WR. The Genital Mycoplasmas. Part I New England Journal of Medicine, 302:1003-1010, 1980.

20. Taylor-Robinson D, McCormack WR. The Genital Mycoplasmas. Part II New England Journal of Medicine 302:1063-1067, 1980 